\title{
New license plate supports youth agricultural programs
}

A gricultural education in California recently got a much needed boost. Last year, the state began issuing new "California Agriculture" license plates that will help fund youth development programs such as 4-H and Future Farmers of America (FFA). The timing could hardly be better. Dedicated funding for the FFA - and California's entire secondary agriculture education curriculum - is far from

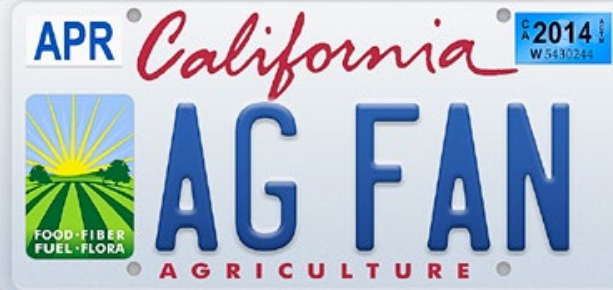

Funds raised by the California Agriculture license plate will go towards CDFA's educational and grant programs.

the sure thing that it

has been for close to a century.

"Funding for career technical student organizations was eliminated in the state budget three years ago - the FFA lost around $\$ 230,000$ annually," says FFA state advisor Bob Heuvel. This year, Gov. Jerry Brown's proposed 2014-2015 state budget cut \$4 million of funding for agriculture education in public schools, but the Legistlature added those funds back to the budget late in the process.

The new license plate could help avoid such funding ups and downs. "It's a way to create some sustainability for agricultural education," Heuvel says. Revenue from these special interest plates can be substantial - altogether, the state's special interest license plate program has raised more than $\$ 630$ million since

\section{Clarification and Correction}

As part of our recognition of UC Cooperative Extension's centennial year, throughout 2014 the research articles in California Agriculture will be paired with short historical sidebars. Some sidebars may draw from the same broad research area, while others may discuss earlier studies of a problem still being investigated or challenged by contemporary scientists. Research that was genuinely new and enlightening at one time may now be taken for granted or even proved wrong. This was the case in our January-June 2014 issue, page 21.

There, a research article on the economic impact to California of Pierce's disease in grapevines was accompanied by a sidebar on one of the most challenging aspects of Pierce's disease at the time: the identification of its causal agent. In 1974, Auger, Shalla and Kado identified a Gram-positive bacterium as the organism causing the disease. Their report was incorrect, as demonstrated 3 years later by Alexander Purcell and collaborators. One year later, in 1978, UC Berkeley graduate student Michael Davis, together with UC professors Purcell and Sherman Thompson, correctly demonstrated that a bacterium now called Xylella fastidiosa was the causal agent of Pierce's disease in grapevines (Davis et al. 1978).

In running historic material we aim to place the university's scientific endeavors into a larger context and remind readers how today's science builds on previous knowledge not confuse people. We regret the latter.

Also in the January-June 2014 issue, the timeline on page 8 listed the year for the founding of the University of California incorrectly. The correct year is 1868. —Editors
1970 for causes such as the arts and the environment. The Lake Tahoe plates alone bring in more than $\$ 1.2$ million per year.

But getting a new license plate approved can be a challenge. The first step was finding a state agency to sponsor the plate. Beginning in April 2010, the California FFA Foundation took the lead on shepherding the license plate through the approval process.

"One of our board members, George Gomes, was the Under Secretary of the California Department of Food and Agriculture (CDFA) at the time," says Jim Aschwanden, executive director of the California Agriculture Teachers' Association and California FFA Foundation board member. "George broached the idea of the CDFA sponsoring the plate, and the response was enthusiastic."

Next, the California Highway Patrol had to sign off on the design of the plate, as logos on special interest plates are now restricted to a 2 -by-3 inch section on the far left. This too went smoothly for the FFA, thanks to a pre-existing logo that had been commissioned several years earlier by San Joaquin Farm Bureau Federation director Bruce Blodgett and others. The logo shows a yellow sun rising over a fertile green crop field and bears the slogan "Food, Fiber, Fuel, Flora."

Before manufacturing a new special interest license plate, the state Department of Motor Vehicles (DMV) requires 7,500 paid pledges within a year. "This was a hard sell because people had to pay up front with no guarantee that the plates would be made," Aschwanden says. "But we have lots of kids who were very enthusiastic about selling them."

Even so, they needed a one-year extension, and "two months before the deadline, we thought we probably wouldn't make it," Aschwanden says. Then he had a bright idea. "We got sponsors so we could give the plates away, up fronting the cost of the first year," he says. "It's a great return on our investment - for example, 7,500 plate renewals would bring in $\$ 300,000$ every year."

The new strategy turned the campaign around, and by the end of the second year in April 2012, more than 8,300 orders had been placed. Last year, the California Agriculture license plates became available on the DMV website (dmv.ca.gov/online/elp/elp.htm).

While the $\$ 50$ fee for the first year goes to offsetting the costs of production, the bulk of the $\$ 40$ annual renewal fee goes to the CDFA.

As one of the first people to order a California Agriculture plate three years ago, Aschwanden is more than ready: "Given the importance of agricultural sector, agricultural education is darned important."

-Robin Meadows 